\title{
RECENZIE A SPRÁVY
}

KĄTNY, Andrzej (Red./Hrsg.): VALENZ UND DEPENDENZ. THEORIE UND PRAXIS. FESTSCHRIFT FÜR PROFESSOR ULRICH ENGEL ZUM 90. GEBURTSTAG. (Studia Germanica Gedanensia 39) Gdańsk: Wydawnictwo Uniwersytetu Gdańskiego 2018. 342 s. ISBN 978-83-7865-710-1.

Už desiatky rokov rezonuje v oblasti jazykovedy meno Ulricha Engla, ktorého dielo je právom považované za medzník v nemeckej a európskej teórii valencie. Významné jubileum tejto výraznej osobnosti nemeckej gramatiky spojilo viacerých domácich i zahraničných germanistov, ktorí s profesorom Englom priamo či nepriamo spolupracovali. Výsledkom sú zaujímavé príspevky vychádzajúce z bohatej výskumnej činnosti jubilujúceho profesora Engla a nadväzujúce na ňu. Týkajú sa oblastí, akými sú valencia, kontrastívna valencia či kontrastívna lexikografia, kde teória priamo a plynule prechádza do empírie. V kontrastívne ladených štúdiách sa nemčina prelína s pol'štinou, rumunčinou, slovenčinou a španielčinou, čo dokazuje, že Englov spôsob nazerania na vzt’ahy v jazyku ovplyvnil i zmýšl’anie v medzinárodnej germanistike.

Prvú čast' zborníka venovanú otázkam valencie a dependencie z teoretického a empirického hl'adiska otvára Henning Lobin (Mannheim). Vo svojom príspevku Bemerkungen zur andauernden Aktualität des Werks von Ulrich Engel (Poznámky k pretrvávajúcej aktuálnosti diela Ulricha Engla) nielen zdôrazňuje, ale i približuje uplatnenie a aktuálnost' princípov Englovej dependenčnej gramatiky, kontrastívnej gramatiky a kontrastívnej valenčnej lexikografie v aplikovaných oblastiach jazykovedy. Autor konštatuje, že koncepcia dependenčnej gramatiky našla vd'aka svojej jednoduchosti a zrozumitel'nosti priame využitie v počítačovej lingvistike, konkrétne v oblasti parsovania - „strojovej analýzy syntaktickej štruktúry viet“ (s. 15), ako i v oblasti strojového prekladu. Bez vplyvu neostala ani konštrukčná gramatika, v ktorej koncept valencie slovesa reprezentuje jednu z hlavných konštrukčnogramatických téz - kontinuum lexikálnej a syntaktickej roviny, z čoho môžu v neposlednom rade vel'mi dobre profitovat' aj kontrastívne orientované výskumy.

María José Domínguez Vázquez (Santiago de Compostela) predstavuje vo svojej štúdii koncepciu Nemecko-španielskeho valenčného slovníka - druhého zväzku monografie Neue Wege zur Verbvalenz (Nové prístupy k verbálnej valencii) (2017), na ktorom sa autorsky podiel'ala spolu s U. Englom a G. Paredesovou Suárezovou. K verbálnej valencii sa uvedený slovník usiluje pristupovat' inovatívne, čo možno badat' napr. pri stavbe heslovej state slovesa, na úrovni lemy a ekvivalentov, pri opise inherentného a relačného významu alebo pri formálnom zachytení vetnej štruktúry a sémantického pol'a. Aj vd’aka týmto vlastnostiam sa Nemecko-španielsky valenčný slovník môže podl'a slov autorky uplatnit' ,pri dizajnovaní a vyhotovení nových lexikografických nástrojov“ (s. 29), akým je napr. projekt MultiGenera slúžiaci na ,automatické generovanie nominálnych fráz, ich argumentov, ako aj foriem realizácie a kombinatoriky“" (s. 29). 
Tému slovesných doplnení prezentuje autorka Meike Meliss (Santiago de Compostela - Mannheim) v príspevku Expansivergänzungen und Verbklassen: Eine inter- und intralinguale Annäherung (Expanzívne doplnenia a triedy slovies: Inter- a intralingválne priblíženie). Za predmet výskumu si zvolila tzv. „expanzívne doplnenie“ (Expansivergänzung), ktoré Engel vo svojej gramatike z roku 2004 charakterizuje ako istý druh adverbiálneho doplnenia označujúceho „mieru zmeny alebo rozširovania v priestore, čase a kvalite“ (citované podl'a recenzovaného zborníka, 2018, s. 35). Primárnym ciel’om štúdie je klasifikácia sémantických tried slovies vyjadrujúcich mieru, s ktorými sa dané špecifické doplnenie môže vyskytovat' bud' obligatórne, alebo fakultatívne. Obligatórny výskyt expanzívneho doplnenia je typický pre a) slovesá pohybu, napr. laufen (bežat'), springen (skočit'), b) slovesá merania, napr. wiegen (vážit'), kosten [stát' (o cene)], c) slovesá (finančnej) transakcie, napr. bezahlen (zaplatit'), gewinnen (získat') a čiastočne pre d) slovesá rozsahu, napr. dauern (trvat'), reichen [(po)stačit', vystačit']. Z početných príkladov možno uviest' napríklad tento: Der Unterricht dauert drei Stunden/einen ganzen Tag (Vyučovanie trvá tri hodiny/celý deň.). Možnými sémantickými atribútmi na realizáciu obligatórneho druhu expanzívneho doplnenia pri jednotlivých triedach slovies sú výrazy so viel (tak vel'a), so weit (tak d'aleko), so lang(e) (tak dlho). Fakultatívna prítomnost' expanzívneho doplnenia je príznačná pre slovesá pomenúvajúce zmenu stavu, ako napr. sinken (klesat'), zunehmen (pribúdat'): In den letzten drei Jahren ist die Zahl der Arbeitslosen unter zwanzig Jahren um ein Viertel gesunken. (Počas posledných troch rokov klesol počet nezamestnaných mladších ako dvadsat' rokov o štvrtinu.). K sémantickým atribútom na realizáciu fakultatívneho druhu expanzívneho doplnenia patria výrazy so viel (tak vel'a), so weit (tak d’aleko). Porovnanie expanzívneho doplnenia $v$ španielčine a nemčine vzhl’adom na jeho morfosyntaktickú realizáciu možno pozorovat' v záverečnej časti príspevku.

Kontrastívny ciel' si vo svojom článku Von Sachverhalt, Tatsache und propositionalen Pro-Elementen: Ein Blick über das Deutsche und Rumänische (Propozicionálne referenčné formy označujúce stav veci, skutočnost': Pohl'ad na nemčinu a rumunčinu) stanovila rovnako Ruxandra Cosma (Bukurešt'), pričom tu vyzdvihuje i vedecký záujem Engla o jazykový pár nemčina - rumunčina. Autorka analyzuje inventár ,propozicionálnych referenčných foriem“ (Pro-Formen) pomenúvajúcich stav veci v oboch jazykoch; pozornost' upriamuje na nemeckú formu stredného rodu das [napr. Das ist Berlin. (To je Berlín.)], ktorej v rumunčine zodpovedá feminínna forma asta (Asta e Berlinul.). Forma das má „,rôznu referenčnú silu“ (s. 59), preto sa $\mathrm{v}$ rumunčine $\mathrm{z}$ dôvodu interpretačnej priezračnosti použiva aj forma ăsta signalizujúca ukazovacie zámeno v mužskom (dieser) alebo v strednom rode (dieses): Asta e Berlinul. s interpretáciou Dies/So ist Berlin (Toto/Taký je Berlín.). Autorkine úvahy podporené jasnou exemplifikáciou ukazujú, že význam referenčných foriem je „komponenciálny, kontextovo podmienený a deskriptívny“ (s. 55).

Bohatú teoretickú a terminologickú základňu ponúka práca Wernera Abrahama (Viedeň - Mníchov) Valenzdiversifikationen: Was ist Thetikvalenz? (Diverzifikácie valencie: Čo je to tetická valencia?). Autor sa v etapovitom a vyčerpávajúcom výklade dotýka oblasti paradigmaticky a syntagmaticky kódovanej valencie, subjektovej valencie a jej špecifickosti a tzv. „tetickej valencie“ (Thetikvalenz), istého typu subjektovej valencie. Typickým príkladom „tetickosti“ sú vety s expletívnym gramatickým subjektom es: Es steht Wasser im Garten. (V záhrade je voda.) Osobitným prípadom tetickej valencie sú aj vety s externým argumentom mir (mne, mi), mich (mňa, ma), ktorý sa môže viazat' napr. so slovesami označujúcimi emócie, pocit’o- 
vanie: Mir graust (vor Würmern). [Mám hrôzu (z červíkov).] Mich schwindelt (beim Balancieren). [Točí sa mi hlava (pri balansovaní.)]. Záver príspevku vyúst'uje do rozčlenenia týchto valenčných typov: syntagmatická, paradigmatická, neakuzatívna, tetická, kauzatívno-tranzitívna a antikauzatívno-intranzitívna valencia.

Štúdia Michaila L. Kotina (Zielona Góra) Valenz und Afinitheit (Valencia a afinítnost') sa zaoberá otázkou syntaktického (valenčného) statusu ,afinitných predikácií“ (afinite Prädikationen) zo synchrónneho, kontrastívno-typologického a diachrónneho hl'adiska. Autor vyčleňuje dvojaký status afinitných syntagiem, a to 1. eliptický [Die Bundeskanzlerin gestern Abend in Warschau eingetroffen. (Spolková kancelárka prišla do Varšavy včera večer.); finitná transformácia sa uskutočňuje prostredníctvom sponového slovesa ist], 2. autonómno-propozičný [napr. gótsky z evanjelia podl’a Matúša, 8. kapitola, 1. verš: hinunter dann steigendem ihm von Berg folgten nach ihm Menschen viele; finitná transformácia daného príkladu prebieha pomocou uvádzacej temporálnej vety: Als er dann vom Berg hinunter stieg, folgten ihm viele Menschen. (Ked' Ježiš zostúpil z vrchu, išli za ním vel'ké zástupy.) $\left.{ }^{1}\right]$. Kotin hodnotí oba druhy afinitných predikácií so zretel'om na „rozvíjanie a formovanie valenčných vlastností infinitívnej časti slovesa (particípia)“ ako „úplné vetné syntagmy“ (s. 99).

Porovnaniu teoretického a metodologického aparátu valenčnej teórie $\mathrm{v}$ germanistike a slovakistike sa venuje príspevok Ruženy Kozmovej (Trnava) Rektion, Valenz, Intention zu einigen Problemen der Abhängigkeitsrelation (Rekcia, valencia, intencia - k niektorým problémom závislostného vzt’ahu). Pri definovaní, ako i relačnom vymedzení pojmov rekcia a valencia sa autorka opiera o publikácie U. Engla (1982, 2004), ktorý v zmysle dependencie považuje valenciu za „subkategoriálno-špecifickú rekciu“ (subklassen-spezifische Rektion) (s. 104), čím sa snaží vyriešit’ otázku t’ažkopádnej klasifikácie oboch pojmov. Ponímanie valencie v slovakistike je späté s výrazom intencia, pričom rozdiel medzi intenčnou a valenčnou teóriou spočíva podl’a autorky v akcentovaní sémantickej roviny v teórii intencie. Tá bola v slovakistike najmä vplyvom Eugena Paulinyho (1943), zakladatel'a slovenskej teórie intencie, jej dominantou a až neskôr zásluhou d’alšej generácie jazykovedcov (J. Ružička, J. Kačala, J. Horecký) sa v teórii valencie a intencie presadil sémanticko-syntaktický model.

Recepcia valenčnej teórie v gramatikách španielskeho jazyka (Die Valenztheorie in der spanischen Grammatikschreibung) je ciel'om článku Andreu Castella (Tarragona). Autor v úvode príspevku poznamenáva, že valenčnej teórii sa v španielskej gramatike nevenoval potrebný a dostatočný priestor a táto teória sa „dlhý čas jednoducho ignorovala“ (s. 122). Prvý dôležitý medzník k explicitnému a systematickému zachyteniu valenčnej teórie možno vidiet’ v dielach $\operatorname{RAE}^{2}$ (1999) a RAE/ASALE ${ }^{3}$ (2009). V uvedených dielach, ale aj vo všetkých ostatných však chýba jasné vymedzenie nosných termínov valencie (napr. Ergänzungen vs. Angaben $)^{4}$ tak, ako to nachádzame v nemeckých gramatikách.

Henrik Nikula (Turku) sa vo svojej štúdii s názvom Vor der Wahl zwischen Dependenz und Konstituenz. Persönliche Erfahrungen (Pred vol'bou medzi dependenciou a konštituen-

\footnotetext{
${ }^{1}$ Evanjelium podl’a Matúša, 8. kapitola, 1. verš. Dostupné na: https:/www.versebiblie.sk/kniha/ $\mathrm{mat} / 8 /$.

${ }^{2}$ Real Academia Española.

${ }^{3}$ Asociación de Academias de la Lengua Española.

${ }^{4}$ V slovakistike sa uplatňujú terminologické dvojice „,aktanty“ vs. „okolnostné doplnenia“, „obligatórne vs. fakultatívne doplnenia“.
} 
ciou. Osobné skúsenosti) zamýšl’a nad ,,prakticko-pragmatickými dôvodmi pri vol'be valenčno-teoretickej koncepcie“ (s. 124, 125). Vychádzajúc z vlastných skúseností opisuje a posudzuje koncept Helbigovej konštitutívnej gramatiky a Englovej dependenčnej gramatiky pre potreby valenčnej teórie. Rovnako si všíma aj vplyv a prienik kontextuálnych (pragmatických) aspektov, vd’aka čomu možno valenčnú teóriu konfrontovat' s novšími lingvistickými smermi, ku ktorým sa zarad’uje napr. konštrukčná gramatika.

Anna Pilarski (Štetín) skúma v práci Das Valenzmodell und die Existenzialkonstruktionen. Eine Untersuchung zu den polnischen Entsprechungen der es gibt-Sätze im Deutschen (Valenčný model a existenciálne konštrukcie. Analýza pol'ských ekvivalentov existenciálnych viet v nemčine) syntaktickú povahu a realizáciu tzv. existenciálnych konštrukcií v pol’štine, ktoré zodpovedajú nemeckým es gibt/es gibt nicht (je, existuje/nie je, neexistuje) vetám s neosobným slovesom geben (byt', existovat'). Z autorkiných analýz vyplýva, že gramatický funkčný subjekt (v nemčine zámeno es) sa v pol’štine z dôvodu jej štruktúrnych vlastností lexikálne nerealizuje: Była mgła. vs. Es gab Nebel (Bola hmla.). Pri negácii dochádza k zmene pádu: z nominatívneho postverbálneho doplnenia sa stáva genitívne doplnenie, ktoré autorka pokladá za objekt: Nie było mgły. vs. Es gab keinen Nebel (Nebolo hmly.). ${ }^{5}$

Jarosław Aptacy (Poznaň) v príspevku Was raten von Sprechen unterscheidet. Zur Behandlung der Kontrollinfinitive in der Dependenzgrammatik und im Minimalistischen Programm [Čo odlišuje sloveso raten (radit', poradit') od slovesa sprechen (hovorit')]. K spracovaniu infinitívov kontroly $\mathrm{v}$ dependenčnej gramatike a $\mathrm{v}$ minimalistickom programe] porovnáva vo svojom príspevku spracovanie tzv. „,infinitívov kontroly“ (Kontrollinfinitive) vo valenčnej gramatike (Engel 1982, 1988, 1999, 2004) a v minimalistickom programe, ktorý reprezentuje „najnovšiu verziu generativizmu“ (s. 150). Aptacy konfrontáciou oboch gramatických teórií zist'uje, ako uvedené koncepcie postupujú napr. v otázke syntaktickej funkcie infinitívneho komplementu alebo v otázke ,referenčných vlastností prázdneho infinitívneho subjektu“ (s. 148) či postavenia tematických rol.

V článku Karstena Rinasa (Olomouc) Dependenz und Konstituenz in der Geschichte der Interpunktionslehre (Dependencia a konštituencia $\mathrm{v}$ dejinách náuky o interpunkcii) sa dozvedáme, že princípy dependencie a konštituencie sa rozvíjali už v antickej náuke o interpunkcii. Vzt’ah hierarchických syntaktických relácií autor ilustruje na príklade rétorickej náuky o perióde (die rhetorische Periodenlehre), kde sa text rozčleňuje „do hierarchicky usporiadaných jednotiek“, a to do „periódy, dvojbodky a čiarky“ (s. 165), ktoré naznačujú prítomnost' interdependencie.

Štúdia Dominiky Janu sovej (Gdansk) Zur Darstellung der Valenz von Phraseologismen in Online-Wörterbüchern für das Sprachenpaar Deutsch und Polnisch (K zobrazeniu valencie frazeologizmov v online-slovníkoch pre jazykový pár nemčina a pol’ština, inšpirovaná Englovou tézou o „uplatnení valenčnej teórie vo frazeológii““ (s. 173), analyzuje lexikografické spracovanie valencie pri frazeologizmoch. Autorka si pre svoj výskum vybrala dva všeobecné nemecko-pol'ské online-slovníky (PONS, DICT.CC) a jeden špeciálny (frazeologický) nemecko-pol'ský online-slovník (FRAZEOLOGIZMY).

${ }^{5}$ Záporový genitív môže byt' v slovenčine „v pozícii predmetu aj v pozícii podmetu“ (Vaňko, 2010, s. 51). V pozícii predmetu genitív ustupuje akuzatívu: nemat' peňazi - nemat' peniaze. Genitívny podmet sa podl'a Vaňka (ibid., s. 53) „drží pri zápornom tvare lokalizačne existenciálneho slovesa byt*: (tu/tam) nikoho nebolo - (tu/tam) nikto nebol. 
Druhá čast' zborníka s názvom Das Deutsche von innen und aussen (Nemčina zvnútra a zvonka) sa začína referátom Wilfrieda Kürschnera (Vechta). Príspevok s titulom Taxierende Attribute (Hodnotiace atribúty) sa zameriava na špecifický typ adjektívnych atribútov vyznačujúcich sa štruktúrou: adjektívum + číslovka + substantívum (udanie miery/početnosti). Úlohou hodnotiacich atribútov je odstupňovanie istého stavu vecí, ako tomu nasvedčujú napríklad tieto doklady: Die Temperatur beträgt milde 10 Grad. (Teplota dosahuje príjemných 10 stupňov./Je príjemných 10 stupňov.); Die Temperatur beträgt kühle 10 Grad. (Teplota klesla na nepríjemných 10 stupňov./Ochladilo sa až na 10 stupňov.).

Kontrastívna práca Hansa-Jörga Schwenka (Lublin) Das semantische Merkmal der Zustandsänderung und seine formdifferenzierende Wirkung am Beispiel des Deutschen und des Polnischen (Sémantický príznak zmeny stavu a jeho vplyv na odlíšenie formy na príklade nemčiny a pol’štiny) zachytáva problematiku tvorenia aspektuálnych dvojíc v nemeckom a v pol'skom jazyku. Na základe formálneho vyjadrenia imperfektívneho a perfektívneho slovesného deja v oboch jazykoch Schwenk uvádza tri skupiny ekvivalentov. V prvej skupine ekvivalentov korešponduje pol'ská imperfektívna forma s nemeckým jednoduchým, neprefigovaným slovesom [płonać - brennen (horiet')] a pol'ská perfektívna forma s nemeckým odvodeným, prefigovaným slovesom [spłonąć - abbrennen (zhoriet')]. Pre druhú skupinu ekvivalentov je príznačné, že pol'skému perfektívu môže v nemčine zodpovedat' aj verbo-nominálne spojenie [dowiedzieć się - erfahren/in Erfahrung bringen (dozvediet' sa)]. V tretej skupine je pol'ské imperfektívum a perfektívum zastúpené jedným nemeckým slovesom, ktoré v sebe združuje obe aspektuálne stránky slovesného deja [budzić, obudzić - wecken ([zo]budit')].

Výskumným zámerom článku Edyty Błachutovej (Vroclav) Vergleichen und Gegenüberstellen als Bewertungsstrategien am Beispiel des Deutschen und des Polnischen (Porovnávanie a konfrontácia ako stratégie hodnotenia na príklade nemčiny a pol’štiny) je analýza lexikálnych a gramatických výrazových prostriedkov, ktoré sa strategicky môžu uplatňovat’ pri realizácii hodnotiacich komunikačných kategórií „,porovnávanie“ (Vergleichen) a „konfrontácia“ (Gegenüberstellen) v nemeckom a v pol’skom jazyku. Pre kategóriu „porovnávanie" sú charakteristickým výrazivom prvky všetkých komparačných stupňov [napr. Salat ist recht gesund, genauso wie Spinat. (Šalát je vel'mi zdravý rovnako ako špenát.) - Sałata jest naprawdę tak samo zdrowa jak szpinak.; modely s prvkami der/aller, über: Buch der Bücher (kniha kníh) - książka książek, książka nad książkami; Meister über Meister (majster nad majstrami) - mistrz nad mistrze]. Kategória „konfrontácia“ môže byt' spätá napríklad s výrazmi statt, anstatt / zamiast [Freiheit statt Angst (sloboda namiesto strachu) - wolność zamiast $\operatorname{strach}(u)$ ] alebo s prítomnost'ou ireálneho podmieňovacieho spôsobu [Hätte der Tourist um Auskunft gebeten, hätte er den Weg in die Stadtmitte schneller gefunden. (Ak by sa turista informoval, našiel by cestu do centra mesta rýchlejšie.) - Jeśliby turysta zapytał kogoś, to szybciej znalazłby droge do centrum.].

Formálnu, významovú i funkčnú stránku pol’ských a nemeckých prepozicionálnych fráz v úlohe adverbií spracúva štúdia Czesławy Schatteovej a Christopha Schatteho (Poznaň) Adverbialisierte Präpositionalphrasen als Grenzbereich von Grammatik und Phraseologie am Beispiel des Polnischen und des Deutschen (Adverbializované prepozicionálne frázy na rozhraní gramatiky a frazeológie na príklade pol’štiny a nemčiny). Podl'a zistení autorov je zrejmé, že adverbializované prepozicionálne frázy môžu okrem povahy adverbia nadobúdat' aj povahu idiómu, vd’aka čomu sa dajú posudzovat' nielen z gramatickej, ale aj z frazeologic- 
kej perspektívy. V analyzovanom materiáli uvádzajú tri druhy spojení: (a) relatívne vol'né spojenia [ani stowem - ohne ein Wort (bez slova), kein Wort (ani slovo)], (b) frazeologizované spojenia s unikátnymi komponentmi [ani chybi - ohne Zweifel (nepochybne, bezpochyby), sicher (určite)] a napokon (c) obrazné frazeologizované spojenia, z ktorých sa stali ustálené prejavy [(ani) o włos - (nicht) um einen Deut ((ani) o vlások/(ani) o chlp)].

Danuta Olszew ska (Gdansk) podáva v práci s názvom Syntaktische Varianz in der deutschen Wissenschaftssprache (Syntaktická variantnost' v nemeckom vedeckom jazyku) detailný výklad syntaktickej variantnosti uplatňujúcej sa v ,jazyku vedy“ (Sprache der Wissenschaft) na príklade komunikačných prostriedkov nemčiny. Celkovo analyzuje pät’ oblastí, v ktorých možno sledovat' súbežnost' v používaní viacerých gramatických štruktúr, pričom tu hovorí o gramatickej synonymii. K typickým syntaktickým prostriedkom vyskytujúcim sa v odborných textoch prirad’uje ich konkurenčné formy (pasívum vs. aktívum, oznamovacia veta vs. opytovacia veta vs. rozkazovacia veta, oznamovací spôsob vs. podmieňovací spôsob perfekta, prítomný čas vs. budúci čas, veta vs. elipsa), čím zároveň poukazuje na ich štylistické a pragmatické rozdiely, ako i na možnost' vol'by, ktorá sa autorom pri organizovaní textu v tomto smere ponúka.

Tematiku tzv. inkluzívneho jazyka so zretel’om na jazykovú realizáciu mužského a ženského rodu pri substantívach $\mathrm{v}$ nemčine na príklade biblických textov opisuje Roman Sadziński (Lodž) v príspevku Genus in ,gerechter Sprache“ (Rod v „,korektnom jazyku“6).

Po problematike nemecko-pol'ského politického diskurzu siaha Waldemar Czachur (Varšava). Predmetom je analýza argumentačnej štruktúry spomienkového prejavu, ktorý 20. novembra 2014 pri príležitosti 25. výročia nemecko-pol'skej bohoslužby zmierenia v Krzyżowej predniesli nemecká spolková kancelárka Angela Merkelová a pol’ská predsedníčka vlády Ewa Kopaczová. V oboch prejavoch autor sleduje jazykovú konceptualizáciu danej udalosti.

Recenzovaný zborník prechádza na tomto mieste do svojej tretej časti, ktorá má výlučne autobiografický charakter. Autoportréty germanistov (Selbstporträts der Germanisten) patria dvom známym lingvistom - Gerdovi Antosovi a Wilfriedovi Kürschnerovi, ktorí predstavujú svoju životnú dráhu formovanú na pozadí jazykovedy.

Bodku za zborníkom dáva zoznam publikácií Ulricha Engla zostavený Andrzejom Kątnym.

Uvedená tematická publikácia poskytuje hodnotný prierez teoretickou a aplikovanou lingvistikou, pričom podčiarkuje najmä význam teórie valencie a jej realizáciu v európskom jazykovom priestore $\mathrm{v}$ rámci gramatických, textuálnych, kontextuálnych a diskurzných analýz.

\section{Bibliografia}

VAŇKO, Juraj: K dynamike v pádovej a predložkovej sústave súčasnej slovenčiny. In: Jazykovedný časopis, 2010, roč. 61, č. 1, s. 43 - 56.

Evanjelium podl’a Matúša, 8. kapitola, 1. verš. Dostupné na: https://www.versebiblie.sk/ kniha/mat/8/.

Lucia Miháliková

Jazykovedný ústav L’udovíta Štúra SAV

Bratislava

\footnotetext{
${ }^{6}$ Rodovo korektný, neutrálny, vyvážený jazyk.
} 